\title{
Anti-CTLA-4 antibodies in cancer immunotherapy: selective depletion of intratumoral regulatory $T$ cells or checkpoint blockade?
}

\author{
Fei Tang ${ }^{1 *}\left(\mathbb{D}\right.$, Xuexiang Du', Mingyue Liu', Pan Zheng ${ }^{1,2}$ and Yang Liu ${ }^{1,2}$
}

\begin{abstract}
Antibodies to human CTLA-4 have been shown to induce long-lasting protection against melanoma. It is assumed that these antibodies cause tumor rejection by blocking negative signaling from the B7-CTLA-4 interactions to enhance priming of naive T cells in the lymphoid organs. Recently, we reported that anti-CTLA-4 antibody Ipilimumab effectively induces tumor rejection in vivo although it blocks neither B7 transendocytosis by CTLA-4 nor CTLA-4 binding to immobilized or cell-associated B7. Using genetic model in which the anti-CTLA-4 antibodies are unable to engage more than $50 \%$ of CTLA-4, we demonstrated that saturating binding of CTLA-4 is not necessary for tumor rejection. Our results argue against B7-CTLA-4 blockade as the mechanism of action for the clinically effective Ipilimumab. Moreover, Ipilimumab induces tumor rejection even in the absence of de novo T cell priming in the lymphoid organs. Thus, our data are inconsistent with key provisions of the prevailing hypothesis on mechanism of action by anti-CTLA-4 antibodies. Furthermore, anti-CTLA-4 antibodies effectively induce depletion of regulatory $T$ (Treg) cells in tumor microenvironment but not in the peripheral lymphoid organs, which is strictly dependent on Fc receptor on host cells. Based on these data and other recent publications on the subject, we propose that anti-human CTLA-4 antibodies induce tumor rejection by selective depletion of Tregs in the tumors rather than blockade of B7-CTLA-4 interaction in lymphoid organs.
\end{abstract}

Keywords: CTLA-4, Ipilimumab, B7-CTLA-4 interaction, Regulatory T cells, Tumor microenvironment, Cancer immunotherapy

In 2011, the FDA approved the first anti-CTLA-4 antibody, Ipilimumab (trademark name YERVOY ${ }^{\circledR}$ ), for the treatment of melanoma. Ipilimumab has demonstrated substantial and durable therapeutic effects, and is now undergoing clinical trials in treating many other cancers. According to the checkpoint blockade hypothesis [1], anti-CTLA-4 antibodies cause tumor rejection by promoting priming of naïve $\mathrm{T}$ cells through blocking the inhibitory B7-CTLA-4 signaling in peripheral lymphoid

\footnotetext{
*Correspondence: ftang@ihv.umaryland.edu

${ }^{1}$ Division of Immunotherapy, Institute of Human Virology

and Department of Surgery, University of Maryland School of Medicine,

725 W Lombard Street, Baltimore, MD 21201, USA

Full list of author information is available at the end of the article
}

organs (Fig. 1). However, this prevailing hypothesis has not been rigorously tested. Ipilimumab was selected according to its ability in blocking the interaction between anchored CTLA-4 and soluble B7 molecules [2]. However, since B7 ligands are co-stimulatory molecules expressed on cell surface, it remains to be tested whether Ipilimumab can effectively block the B7-CTLA-4 interactions under physiological conditions.

Recently, we compared multiple anti-CTLA-4 monoclonal antibodies (mAbs) for their abilities to block B7-CTLA-4 interactions under various settings [3]. We found that when B7 molecules were immobilized on solid phases (such as when B7-1 or B7-2 was coated on ELISA plates or expressed on cell surface), Ipilimumab was unable to block the interaction between B7 and

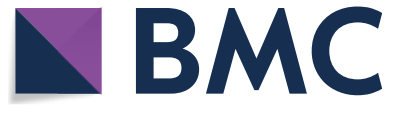

(c) The Author(s) 2018. This article is distributed under the terms of the Creative Commons Attribution 4.0 International License (http://creativecommons.org/licenses/by/4.0/), which permits unrestricted use, distribution, and reproduction in any medium, provided you give appropriate credit to the original author(s) and the source, provide a link to the Creative Commons license, and indicate if changes were made. The Creative Commons Public Domain Dedication waiver (http://creativecommons.org/ publicdomain/zero/1.0/) applies to the data made available in this article, unless otherwise stated. 


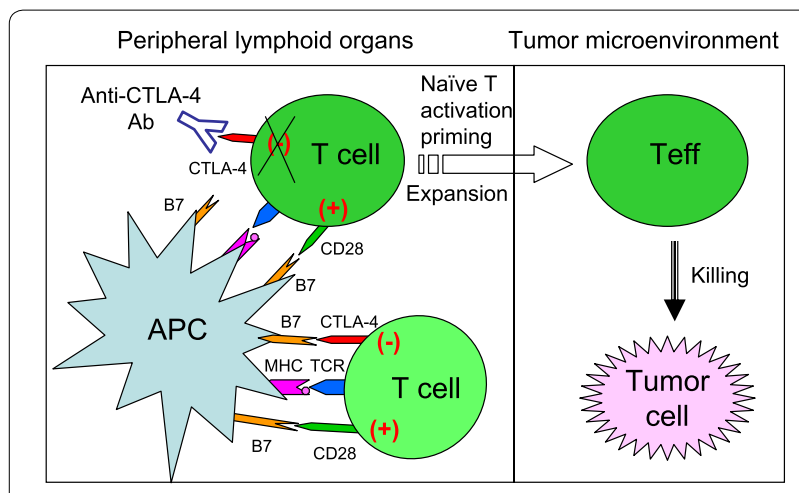

Fig. 1 The prevailing view: CTLA-4 checkpoint blockade results in tumor immunity. Activation of T cells requires two signals. One is the binding of the T cell receptor (TCR) to the MHC-antigen peptide complex presented by antigen presenting cells (APCs) (signal 1). The other one is the binding of B7 molecules (B7-1 or B7-2) to the co-stimulatory (+) molecule CD28 on the surface of T cells (signal 2). With higher affinity than $C D 28$, inhibitory (-) CTLA-4 binds to B7 ligands on APCs and provides a brake for T cell activation. AntiCTLA-4 antibodies were proposed to release brakes of naïve T cells and allow them to be activated in the lymphoid organs and then migrate to tumors to cause tumor rejection

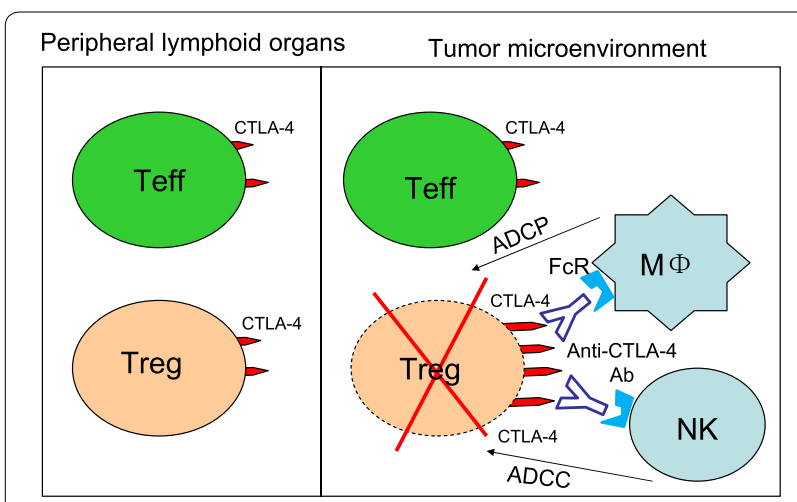

Fig. 2 New concept: selective depletion of Tregs in the tumor microenvironment results in tumor immunity. Higher levels of CTLA-4 on intratumoral Tregs allow their selective depletion by anti-CTLA-4 antibodies, perhaps through antibody-dependent cellular phagocytosis (ADCP) by macrophages and/or antibody-dependent cellular cytotoxicity (ADCC) by NK cells. Blocking of B7-CTLA-4 interaction is not required for effective depletion of intratumoral Treg cells

CTLA-4 [3]. On the contrary, L3D10, one anti-CTLA-4 antibody generated in our lab $[4,5]$, can block the in vitro interactions between various forms of CTLA-4 and B7 molecules [3]. Similar trend was observed when CTLA4-mediated transendocytosis was measured. Consistent with this finding, we found that L3D10, but not Ipilimumab, significantly inhibited CTLA-4-mediated downregulation of $\mathrm{B} 7$ on the surface of splenic dendritic cells in CTLA $4^{\mathrm{h} / \mathrm{h}}$ humanized mice and human $\mathrm{CD} 34^{+}$ stem cell reconstituted mice, providing in vivo evidence that Ipilimumab is ineffective in blocking B7-CTLA-4 interaction under physiological conditions [3].

Despite the differences in blocking B7-CTLA-4 interaction, L3D10 and Ipilimumab are comparable in inducing anti-tumor activity [3]. In addition, the fully humanized L3D10 clones, HL12 and HL32, which lose the ability to block B7-CTLA-4 interaction, remain fully active in inducing tumor rejection. Together, the above data demonstrate that blockade of B7-CTLA-4 interaction is unnecessary for immunotherapeutic effect of anti-CTLA-4 antibodies. In CTLA $4^{\mathrm{h} / \mathrm{m}}$ heterozygous mice, which express mouse and human CTLA-4 molecules in a codominant manner, anti-human CTLA-4 antibodies are unable to engage more than $50 \%$ of CTLA- 4 as the remaining $50 \%$ of the molecules are of mouse origin and thus lack reactivity to antibodies originally made in mice [3]. However, all anti-CTLA-4 antibodies caused robust tumor rejection in CTLA $4^{\mathrm{h} / \mathrm{m}}$ mice. Therefore, even for blocking antibodies, their ability to completely block B7-CTLA-4 interaction is not required for effective tumor immunotherapy.

Finally, we reasoned that since antibody treatment is initiated after $\mathrm{T}$ cell priming has already taken place in the lymphoid environment, it is possible that antiCTLA-4 antibodies may promote tumor rejection even if their effect in de novo $\mathrm{T}$ cell priming is abrogated. We tested if Ipilimumab can cause tumor rejection if de novo $\mathrm{T}$ cell priming is shut down by complete blockade of B7 by anti-B7 antibodies. Our results demonstrated that while anti-B7 antibodies effectively blocked de novo $\mathrm{T}$ cell priming in lymphoid organs, Ipilimumab remained fully active in causing tumor rejection in the presence of saturating B7 blockade [3]. These data refute the idea that anti-CTLA-4 antibodies cause tumor rejection by promoting $\mathrm{T}$ cell priming in the lymphoid organs.

What then is the primary mechanism of anti-CTLA-4 antibody induced tumor rejection? Several groups have established that anti-mouse CTLA-4 antibodies induced tumor rejection through selective depletion of regulatory $\mathrm{T}$ (Treg) cells in the tumor microenvironment [6-8]. By showing selective Tregs depletion in tumor microenvironment by anti-CTLA-4 antibodies as well as the absolute requirement of $\mathrm{Fc}$ receptor (FcR) in Ipilimumabinduced tumor rejection [3], our work demonstrates that the effector mechanism of anti-human CTLA-4 antibodies is similar to that reported by anti-mouse CTLA-4 antibodies (Fig. 2).

Therefore, rather than focusing on enhancing the blocking of B7-CTLA-4 interaction, other approaches on promoting local intratumoral Tregs clearance should be attempted in order to optimize the therapeutic effect of anti-CTLA-4 antibodies. 


\section{Abbreviations}

APC: antigen presenting cell; CTLA-4: cytotoxic T-lymphocyte associated protein 4; FcR: Fc receptor; MHC: major histocompatibility complex; NK: natural killer; TCR: T cell receptor; Teff: effector T cells; Treg: regulatory T cells.

\section{Authors' contributions}

FT wrote the original manuscript. YL and PZ revised the manuscript. All authors read and approved the final manuscript.

\section{Author details}

1 Division of Immunotherapy, Institute of Human Virology and Department of Surgery, University of Maryland School of Medicine, 725 W Lombard Street, Baltimore, MD 21201, USA. ${ }^{2}$ Oncolmmune, Inc., 9430 Key West Avenue, Rockville, MD 20850, USA.

\section{Acknowledgements}

We would like to thank Juanjuan Su, Yan Zhang, Peng Zhang, Peiying Ye, Xu Wang, Wei Wu and other colleagues in our research team for discussions.

\section{Competing interests}

Drs. Yang Liu and Pan Zheng are co-founders of, and have equity interests in Oncolmmune, Inc. The authors declare that they have no competing interests.

\section{Availability of data and materials}

Data sharing not applicable to this article as no datasets were generated or analyzed during the current study.

\section{Consent for publication}

Not applicable.

\section{Ethics approval and consent to participate}

Not applicable.

\section{Funding}

This work is supported by NIH Grants (Al64350, CA171972 and AG036690) and a grant from Oncolmmune, Inc.

\section{Publisher's Note}

Springer Nature remains neutral with regard to jurisdictional claims in published maps and institutional affiliations.
Received: 24 March 2018 Accepted: 13 April 2018

Published online: 18 April 2018

\section{References}

1. Korman AJ, Peggs KS, Allison JP. Checkpoint blockade in cancer immunotherapy. Adv Immunol. 2006;90:297-339.

2. Keler T, Halk E, Vitale L, O'Neill T, Blanset D, Lee S, Srinivasan M, Graziano RF, Davis T, Lonberg N, Korman A. Activity and safety of CTLA-4 blockade combined with vaccines in cynomolgus macaques. J Immunol. 2003;171:6251-9.

3. Du X, Tang F, Liu M, Su J, Zhang Y, Wu W, Devenport M, Lazarski CA Zhang P, Wang $X$, et al. A reappraisal of CTLA-4 checkpoint blockade in cancer immunotherapy. Cell Res. 2018. https://doi.org/10.1038/ s41422-018-0011-0.

4. Lute KD, May KF Jr, Lu P, Zhang H, Kocak E, Mosinger B, Wolford C, Phillips G, Caligiuri MA, Zheng P, Liu Y. Human CTLA4 knock-in mice unravel the quantitative link between tumor immunity and autoimmunity induced by anti-CTLA-4 antibodies. Blood. 2005;106:3127-33.

5. May KF Jr, Roychowdhury S, Bhatt D, Kocak E, Bai XF, Liu JQ, Ferketich AK, Martin EW Jr, Caligiuri MA, Zheng P, Liu Y. Anti-human CTLA-4 monoclonal antibody promotes T-cell expansion and immunity in a hu-PBL-SCID model: a new method for preclinical screening of costimulatory monoclonal antibodies. Blood. 2005;105:1114-20.

6. Bulliard $Y$, Jolicoeur R, Windman M, Rue SM, Ettenberg S, Knee DA, Wilson NS, Dranoff G, Brogdon JL. Activating Fc gamma receptors contribute to the antitumor activities of immunoregulatory receptor-targeting antibodies. J Exp Med. 2013;210:1685-93.

7. Selby MJ, Engelhardt JJ, Quigley M, Henning KA, Chen T, Srinivasan M, Korman AJ. Anti-CTLA-4 antibodies of IgG2a isotype enhance antitumor activity through reduction of intratumoral regulatory $T$ cells. Cancer Immunol Res. 2013;1:32-42.

8. Simpson TR, Li F, Montalvo-Ortiz W, Sepulveda MA, Bergerhoff K, Arce F, Roddie C, Henry JY, Yagita H, Wolchok JD, et al. Fc-dependent depletion of tumor-infiltrating regulatory $T$ cells co-defines the efficacy of antiCTLA-4 therapy against melanoma. J Exp Med. 2013;210:1695-710.

Ready to submit your research? Choose BMC and benefit from:

- fast, convenient online submission

- thorough peer review by experienced researchers in your field

- rapid publication on acceptance

- support for research data, including large and complex data types

- gold Open Access which fosters wider collaboration and increased citations

- maximum visibility for your research: over 100M website views per year

At $\mathrm{BMC}$, research is always in progress.

Learn more biomedcentral.com/submissions 